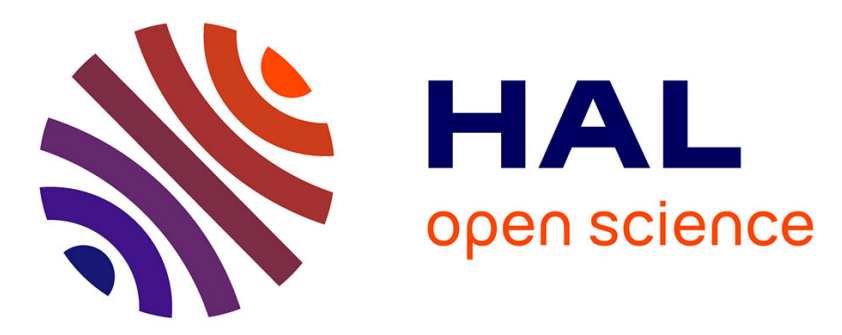

\title{
Conventionalisation of organic farming practices: from structural criteria towards an assessment based on organic principles. A review
}

Ika Darnhofer, Thomas Lindenthal, Ruth Bartel-Kratochvil, Werner Zollitsch

\section{- To cite this version:}

Ika Darnhofer, Thomas Lindenthal, Ruth Bartel-Kratochvil, Werner Zollitsch. Conventionalisation of organic farming practices: from structural criteria towards an assessment based on organic principles. A review. Agronomy for Sustainable Development, 2010, 30 (1), 10.1051/agro/2009011. hal-00886488

\section{HAL Id: hal-00886488 \\ https://hal.science/hal-00886488}

Submitted on 1 Jan 2010

HAL is a multi-disciplinary open access archive for the deposit and dissemination of scientific research documents, whether they are published or not. The documents may come from teaching and research institutions in France or abroad, or from public or private research centers.
L'archive ouverte pluridisciplinaire HAL, est destinée au dépôt et à la diffusion de documents scientifiques de niveau recherche, publiés ou non, émanant des établissements d'enseignement et de recherche français ou étrangers, des laboratoires publics ou privés. 


\title{
Conventionalisation of organic farming practices: from structural criteria towards an assessment based on organic principles. A review
}

\author{
Ika DARNHOFER*, Thomas LINDENTHAL, Ruth BARTEL-KRATOCHVIL, Werner ZOLLITSCH
}

BOKU - Univ. of Natural Resources and Applied Life Sciences, Vienna, Feistmantelstr. 4, 1180 Vienna, Austria

(Accepted 8 April 2009)

\begin{abstract}
Organic farming is widely perceived as being more environmentally friendly than conventional farming. As a form of sustainable agriculture, it receives substantial support from policy for its contribution to environmental protection as well as the provision of amenities such as biodiversity and cultural landscapes. Consumers are attracted to organic foods as they are produced without synthetic chemicals and comply with higher animal welfare standards. Although organic farming certainly has the potential to fulfil these expectations, studies have shown that some certified organic farms do not. Their practices comply with the regulations, but not with the principles of organic farming. This trend has been called 'conventionalisation' of organic farming. In this paper we review the studies that discuss the conventionalisation of organic farming, focusing on the farm level and on evidence from Europe. We argue that to strengthen organic farming's transformative potential, the debate must move beyond its focus on the bifurcation between artisanal and conventionalised organic farms, so as to capture the full range of empirical heterogeneity. Our core argument is that to adequately understand the dynamics within organic farming and their potential impact on the ability of organic farming to fulfil the expectations of consumers and policy-makers, it is not sufficient to focus on structural changes. Instead, we need to assess whether or not the observed changes comply with the principles and values that are the fundament of organic farming.
\end{abstract}

organic agriculture / conventionalisation debate / Europe / plant production / animal husbandry

\section{Contents}

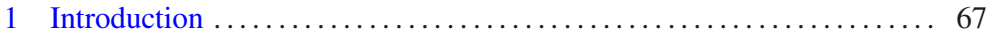

2 An overview of the conventionalisation debate .............. 69

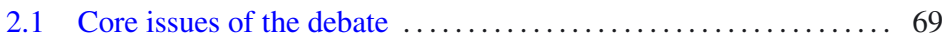

2.2 Conventionalisation in the European context ........... 70

2.3 Shortcomings of the debate surrounding the conventionalisation

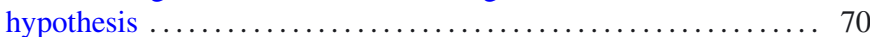

3 A more discerning approach to studying change in organic farming... 71

4 Towards principle-based indicators of conventionalisation ........ 73

4.1 Organic farming as value-based agriculture $\ldots \ldots \ldots \ldots \ldots \ldots 73$

4.2 Exploring options for building an assessment framework ...... 73

4.3 Examples of potential indicators for conventionalisation....... 75

5 Conclusion ........................................... 75

\section{INTRODUCTION}

Organic farming was developed in the 1940s in Switzerland by Hans Müller, Maria Biegler and Hans Peter Rusch, as well as in the United Kingdom by Lady Eve Balfour and Sir Albert Howard. Their developments were based in part on the concepts of biodynamic farming initiated in the $1920 \mathrm{~s}$ by Rudolf Steiner in Germany. However, it was only in the 1980 s, when the negative impact of intensive conventional

* Corresponding author: ika.darnhofer@boku.ac.at 
agricultural methods became apparent, that interest in organic farming reached a broader public. In the European Union (EU) organic farming has received policy support since the early 1990s for its potential to contribute to environmental protection, rural development and animal welfare (EC, 2004; Häring et al., 2004; Nieberg et al., 2007). Organic farming is also linked to the production of quality food, and policies have been implemented to ensure transparency and fair competition on the market. Support by consumers and by policy-makers has resulted in a sizeable uptake of organic farming methods. In 2005, around 4\% of the Utilised Agricultural Area of the 25 Member States of the EU was certified organic, representing over 6 million ha and nearly 158000 organic producers (Eurostat, 2007). In the last decade the market for organic products has grown steadily, both in Europe and elsewhere, and is expected to keep increasing (Michelsen et al., 1999; Willer et al., 2008).

Research on agronomic aspects of organic farming has shown that crop yields tend to be lower in organic farming (Mäder et al., 2002; Kaut et al., 2008), albeit less variable and less susceptible to drought (Lotter, 2003). Organic farming methods tend to increase soil organic matter and thus enhance soil fertility (Langmeier et al., 2002; Mäder et al., 2002), making it less dependent on external inputs. Organic farming may also provide ecosystem services, increase biodiversity and have a positive impact on the landscape (Letourneau and Bothwell, 2008; Norton et al., 2009). However, studies have pointed out that the potential benefits of organic farming are not always realised in all places and under all management systems (e.g., Trewavas, 2001; Rigby and Cáceres, 2001; Degré et al., 2007; Letourneau and Bothwell, 2008).

In the social sciences, there have been numerous studies on reasons for farmers to convert to organic farming (e.g., Fairweather, 1999; Padel, 2008) and for consumers to purchase organic foods (e.g., Brand, 2006; Holt, 2006). Research has also addressed the potential of organic farming to contribute to endogenous rural development, through fostering direct producer-consumer relationships (e.g., Moore, 2008; Renting et al., 2008; DuPuis and Gillon, 2009) or through service provision (e.g., Darnhofer, 2005; Schermer, 2006; Frederiksen and Langer, 2008; Lobley et al., 2009). Finally, a number of researchers have analysed the influence of legal regulations as well as of the entry of agribusiness and supermarkets into the organic food chain (e.g., Allen and Kovac, 2000; Alrøe and Noe, 2008; Tomlinson, 2008). However, as Lamine and Bellon (2009) have shown, there has been little dialogue between the agricultural and social sciences as well as a general lack of emphasis on the trajectories of organic farms and the understanding of transitions.

Transitions in organic agriculture and the trajectories of organic farms play a central role in the debate surrounding the conventionalisation hypothesis. The hypothesis was first put forward by Buck, Getz and Guthman in 1997 and has led to an on-going, intense debate on how the developments within organic farming can be understood and which patterns can be discerned. The debate essentially hinges on two aspects: whether the developments observed in the organic vegetable sector in California are universal and whether they are inevitable.

According to the conventionalisation hypothesis, organic farming is becoming a slightly modified version of modern conventional agriculture, replicating the same history, resulting in many of the same social, technical and economic characteristics (Buck et al., 1997; Hall and Mogyorody, 2001; Guthman, 2004a). Organic farming could thus be subjected to 'industrialisation', i.e. the implementation of economies of scale at the farm level (larger farms), increased reliance on purchased non-farm inputs (machinery, fertilisers, feed, agrichemicals), resource substitution (capital for land and labour), implementation of organisational features associated with the concept of the 'firm', and mechanisation of the production process (Bowler, 1992). These mechanisms have been observed both at the farm level as well as in processing and marketing of organic food (Guthman, 2004a).

Conventionalisation is widely seen as problematic since organic farming has received public support for its potential to contribute to environmental protection and rural development (CEC). However, if organic farming increasingly comes to resemble conventional farming, this potential contribution is jeopardised, and organic farming might lose the support it currently receives from both consumers and policy-makers.

In this paper we present a brief review of the debate that has surrounded the conventionalisation hypothesis. We also discuss the empirical evidence that has been gathered to support and modify this hypothesis. We focus on the contributions from the $\mathrm{EU}^{1}$ as the Common Agricultural Policy and the multifunctional model of agriculture are likely to offer different opportunities and constraints to organic farms than liberal agricultural policies. We will argue that a number of the 'symptoms', that have been used to identify conventionalisation at the farm level, may not be reliable indicators and that they are thus not well suited to achieve a comprehensive assessment of the type and direction of changes in organic farming. To overcome these weaknesses, we suggest that it may be necessary to design an assessment framework that is explicitly based on the ethical principles and values that are the foundation of organic farming. Such an assessment framework could be used both to assess the 'level of conventionalisation' on individual organic farms and to guide their development in accordance with the principles.

In this paper we will focus on conventionalisation at the farm level rather than taking an agrarian political economy approach. This in no way denies the importance of sophisticated, comprehensive studies of food networks (e.g. Goodman, 1999; Green and Foster, 2005; Brand, 2006; Lockie et al., 2006; Follett, 2009), nor does it indicate that we are not aware of the fact that all farmers operate within a larger political and economic framework that affects their agronomical practices (e.g., Allen and Kovach, 2000; DeLind, 2000; Guthman, 2004b; Thomas and Groß, 2005; Obach, 2007; Alrøe and Noe, 2008;

\footnotetext{
${ }^{1}$ Especially in the 15 Member States of the former EU-15, as the Member States that joined the EU since 2004 tend to have a different agricultural structure and heritage, stemming from past socialist policies.
} 
Tomlinson, 2008). We also fully acknowledge the importance of consumer motivations (Lockie et al., 2002; Bähr et al., 2004; Padel and Foster, 2005; Holt, 2006) and the role supermarkets can play (Burch and Lawrence, 2005; Konefal et al., 2005 ) in the development of organic farming. However, we argue that if the imperative of agricultural intensification undermines the potential of organic farming to contribute to agricultural sustainability, then there should be clear evidence at the farm level. Also, as organic quality is mostly based on the production process, it is in large part defined by what happens at the farm level. Arguably, conventionalisation should lead to tangible changes in farm practices, which would threaten the core identity of organic farming. The farm is thus probably the most important level mediating the various influences exerted by the different scales in the hierarchies of agri-food networks.

\section{AN OVERVIEW OF THE CONVENTIONALISATION DEBATE}

\subsection{Core issues of the debate}

Trends towards conventionalisation were first reported from California (Buck et al., 1997; Guthman, 2004a), where highvalue crops within the organic vegetable commodity chain were being appropriated by conventionally-based agribusiness. Many of these commercial farms were abandoning the more sustainable agronomic and marketing practices associated with organic agriculture (Guthman, 2000, 2004a). A first thread of the conventionalisation debate thus tries to assess whether such developments can also be identified in other locations and if so, how widespread such developments are. The relevant evidence from international studies has been reviewed by Lockie et al. (2006). They conclude that case studies from around the world, e.g. by Hall and Mogyorody, 2001; Lockie and Halpin, 2005; Jordan et al., 2006, show that concentration, de-localisation, institutionalisation and input substitution certainly are occurring to a significant extent (Lockie et al., 2006).

A second thread of the conventionalisation debate hinges on whether conventionalisation affects all farms equally, or whether there might be a 'bifurcation' of the organic sector (see Fig. 1). A bifurcation would result if conventionalisation primarily affects large operations that specialise in massproducing a few high-growth, high-profit crops (Coombes and Campbell, 1998). The smaller, 'artisanal' farms continue to implement diversification strategies, using artisanal methods to grow a variety of marketable crops (Buck et al., 1997; Coombes and Campbell, 1998). This thread of the debate focuses on the ability of these 'artisanal' organic farms to resist the economic pressures exerted by the large operations, i.e. their ability to survive in the long term and ensuring that conventionalisation does not spread to all organic farms.

Guthman (2004b) has argued that agribusiness involvement unleashes the logic of intensification and therefore alters the conditions under which all organic growers operate. Through their control over processing and marketing, and through their introduction of industrial inputs, agribusinesses

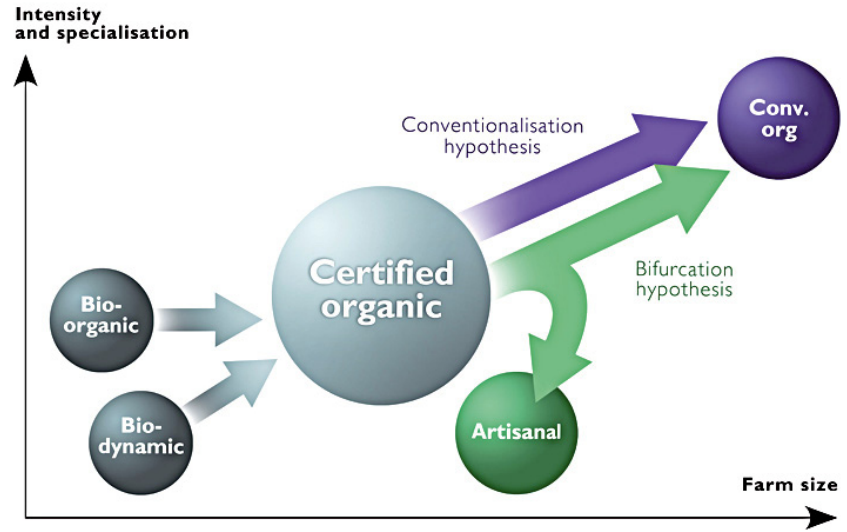

Figure 1. Schematic development of organic farming from the pioneers in bio-dynamic and bio-organic farming in the 1940s towards certified organic farming in the 1990s and expected further development according to the conventionalisation and the bifurcation hypotheses. (Note: the graphic is indicative of trends and is not based on empirical data.)

make the smaller operations less profitable, as they compete directly with the larger producers on the same markets. This puts pressure on the artisanal organic farmers to adopt conventional cropping, labour and marketing practices if they are to survive. The growing constraints in decision-making, coupled with increases in the economic pressures farmers face, could thus cause an erosion of the ethical attitudes and behaviours of farmers (Hendrickson and James, 2005).

Other authors, although acknowledging these pressures, have emphasised the smallholder's ability to resist concentration and specialisation and have pointed out that a number of factors countervail conventionalisation (Coombes and Campbell, 1998; Lockie et al., 2006; Guptill, 2009). These include the technology barriers faced by larger and more monocultural operations; the biological limits to input substitution; the ability of household-based enterprises to cope with unfavourable returns through self-exploitation and reduced consumption; the competitive advantage of small enterprises in a range of markets and under a range of policy conditions; their ability to target market niches; as well as consumer demands for what are perceived to be local, speciality products. Coombes and Campbell (1998), in their analysis of the development of organic farming in New Zealand, not only emphasise that smallholders are expected to survive, but also show that the relationship between small and large growers may well be complementary. Indeed, larger actors may initiate research and market development, and/or focus on different products or markets.

The various contributions to the conventionalisation debate have thus shown that although symptoms of conventionalisation can be identified fairly easily, a widespread conventionalisation of organic farming is (still) constrained. This conclusion needs to be understood as being based on case studies in countries with a liberalised agricultural policy, e.g. California (USA), Ontario (Canada), New Zealand and Australia. In 
such a context, farmers receive few or no subsidies and are thus more likely to be affected by the vagaries of market forces. However, as Guthman (2004b) points out, the type and degree of state support along with the agrarian structures on which organic farming was built are likely to have a strong influence on the extent, severity and pervasiveness of conventionalisation.

\subsection{Conventionalisation in the European context}

In the EU, agriculture is characterised by a vast majority of family farms and a minority of corporate farms. The Common Agricultural Policy has embraced the concept of multifunctional agriculture, thus recognising that farms not only produce food, but also provide services such as landscape amenities, recreational space, environmental protection and preservation of cultural heritage. Whereas large-scale agriculture may be efficient in producing food and fibre, smallscale farms tend to be more efficient in supplying services that are valued at a local level. Farms thus receive direct payments for the provision of public goods. This supportive policy environment creates a different set of opportunities for organic farmers.

Still, case studies assessing the changes in organic farming in Europe report on trends and practices that could indicate conventionalisation processes. For example, the size of organic farms is increasing, e.g. in Denmark (Langer and Frederiksen, 2005) and in Germany (Best, 2008). An analysis of dairy herds in Norway shows that later entrants tend to have a higher level of registered disease treatments per cow, and an intensification of milk production based on a higher use of concentrates (Flaten et al., 2006). Smith and Marsden (2004) point out that the over-supply of some organic products (e.g., milk) has led to a 'farm-based cost-price squeeze' in the UK, which might be forcing farmers into progressively more intense production strategies. Best (2008) finds that later entrants seem to be somewhat less concerned about the environment. He also reports fewer mixed farms and a drop in direct marketing. De Wit and Verhoog (2007) report conventionalisation trends in organic pig and poultry production in the Netherlands. Conventionalisation has also been reported from arable farming, where permitted fertilisers of conventional origin are increasingly used (e.g. vinasse, a byproduct of the sugar beet industry). The intensive use of fertiliser has resulted in mineral surpluses in the soil and higher nitrate levels, e.g. in organic carrots (De Wit and Verhoog, 2007; Padel et al., 2007). Despite these symptoms of conventionalisation, a Europe-wide study concludes that conventionalisation does not (yet) seem to be a dominant phenomenon in organic farming as a whole (De Wit and Verhoog, 2007).

Thus, in Europe as elsewhere, some organic farms are implementing practices that may not be sustainable but that are not explicitly prohibited by the standards (Padel et al., 2007). Certified organic farming by itself is thus no guarantee for its alternativeness, as has been pointed out by Guthman (2004b). The question thus arises whether the symptoms that have been identified indicate that conventionalisation is progress- ing, thus undermining the potential contribution of organic farming both to quality food and to environmental protection. To answer this question it is not only necessary to assess whether the identified practices are spreading, it is also necessary to assess whether the practices and symptoms reported in the studies are valid and reliably indicate the conventionalisation of organic farming.

\subsection{Shortcomings of the debate surrounding the conventionalisation hypothesis}

When critically assessing the methods used in the various studies, a range of weaknesses can be identified. Most of these are due to the fact that the available data does not allow one to sufficiently capture the heterogeneity and complexity of the on-going processes within organic farming. Indeed, there has been a focus on analysing aggregated statistical data, and there has been a lack of distinction between farm types, e.g. parttime vs. full-time farmers or corporate vs. family farms. Furthermore, there is a lack of statistical time-series data to ascertain long-term trends. In this section we review some of the approaches leading to conclusions that are based on circumstantial evidence rather than on valid variables and rigorous analysis of comprehensive data sets.

One of the methodological weaknesses lies in comparing early converters with later converters and deriving conclusions on the change in attitudes, values and practices of organic farmers. In this approach, a small group of pioneers who have been organic for an extended period of time are compared with farmers who have limited experience with organic farming as they converted recently. This comparison is fundamentally problematic, as it tends to ignore the learning processes leading to change in knowledge and attitudes that farmers undergo after conversion (Padel, 2008). To reliably assess changes in attitudes, a longitudinal study of both early and later converters would be required, but none has been reported so far.

A similar weakness can be found in studies that analyse aggregated statistical data and assess changes in the 'average' organic farm at two points in time. These studies often conclude that organic farms are now larger than they used to be, or that they are more specialised than they used to be. These changes are then assumed to derive from farmers' preferences, indicating conventionalisation of on-farm practices. The problem with this approach is that the influence of changes in the wider environment (markets, policies, technologies) tends to be under-theorised. The identified differences may thus be the result of processes that are not linked to conventionalisation. For example, a reduction in the share of organic farms involved in animal keeping might be due to the spread of organic farming in a new agro-ecological environment, i.e. a new cohort of organic farms, rather than different practices by the same cohort. For instance, in Austria most organic farms in the period 1995-2000 were grassland-based dairy farms. After the year 2000 arable farms started converting to organic farming, but these had few, if any, animals even prior to conversion. Similar shifts in the national composition of organic farms were also reported from Denmark (Langer, 2002). Thus, data indicating 
changes in the 'average' organic farm must be interpreted carefully, so as not to infer unwarranted causal links.

Unwarranted conclusions can also be the result of a lack of distinction between farm types, e.g. because the survey sample is not large enough or because the official statistics do not contain the necessary variables. However, capturing the heterogeneity of organic farms is important as it is likely that different farm types, e.g. full-time vs. part-time farmers, family farms vs. corporate farms, mixed farms vs. grasslandbased dairy farms (which are often found in less favoured areas), have different options to face market pressures and price squeezes. Indeed, as part-time farmers derive most of their household income from off-farm work, they are not affected by market pressures to the same extent as corporate farms (Best, 2008). This type of distinction is important, as in many European countries, a large share of farms are managed part-time: in the sample surveyed by Best (2008) 68\% were part-time farmers; in Austria $61 \%$ of all farmers are part-time farmers (BMLFUW, 2007). To be able to accurately capture conventionalisation would require an analysis differentiating between, e.g., farm types, commodities and marketing channels. Only then will it be possible to do justice to the complexity of organic production (Sylvander et al., 2006; Rosin and Campbell, 2009; Lamine and Bellon, 2009).

The lack of an adequate, nuanced analysis has also been raised by Lockie and Halpin (2005, p. 287), who point out that the binary opposition between 'artisanal' and 'industrial', between 'lifestyle' and 'agribusiness' producers, can be problematic, as it "conflates differences in economic scale with differences in production practices, market relationships and grower motivations that have not been empirically verified". They thus point out the need to "unpack the concept of conventionalisation and avoid the uncritical aggregation of multiple dualisms between small and large, artisanal and industrial, radical and regulatory, local and international, regenerative and substitutionist, and so on through the related concept of bifurcation" (Lockie and Halpin 2005, p. 304).

At a more general level, the conventionalisation debate also suffers from resting on implicit and poorly justified stereotypes. As Langer and Frederiksen (2005) have pointed out, conventionalisation builds on the notion that until a decade or two ago organic farms were smaller, less specialised and less intensive than conventional farms, and that this might now be changing. This assertion regarding 'early' organic farms is often made, although there is little (if any) historical data on organic farms. We thus do not have sufficient data to ascertain whether they all were mixed farms or whether there has always been a certain level of heterogeneity. The stereotype of the 'small' organic farm is also surprising, as in most European countries organic farms are larger than conventional farms: the average size of organic holdings in the EU-25 in 2005 was 38.7 ha, compared with 16.0 ha for all holdings (Eurostat, 2007). In this context, an increase in farm size is hardly an indication of a convergence between organic and conventional farms. Thus, whereas conventionalisation has been linked to increased farm sizes, the converse need not be true: not every instance of scale increase necessarily indicates conventionalisation.
The conventionalisation debate may also have suffered from being mostly conducted by social scientists. Due to the dearth of interdisciplinary studies (Watson et al., 2008; Lamine and Bellon, 2009), the links between the changes noted by social scientists and the agronomic practices of farmers have not been established. In other words, the implied effect of the changes within organic farming on variables indicating environmental protection, sustainable plant production, animal welfare and soil fertility is rarely based on empirical evidence. For example, a reduction of mixed farms and of animal keeping is hypothesised to indicate a stronger reliance on off-farm fertiliser and thus input substitution. However, before reaching this conclusion, it would be important to assess whether the number of animals kept in the first place was sufficient to cover the nutrient needs of the field crops. Indeed, from an agronomic point of view it would be hard to argue that 100 growing-fattening pigs make a sizeable contribution to nutrient cycling on a 50-ha crop farm. Thus, if the conventionalisation debate is to be relevant to practitioners and inform them about the development options within organic farming, then the debate will need to integrate other disciplines into the discourse, e.g., crop and livestock production scientists as well as soil scientists.

Overall, we conclude that despite the case studies reporting symptoms that have been linked to it, the available data is inadequate to confirm or to refute the conventionalisation hypothesis in the European context. This is not least due to the fact that the variables used to identify the changes do not reliably indicate conventionalisation and that the available data does not allow for the nuanced analysis required to adequately capture the heterogeneity of organic farms or the complexity of the change dynamics.

\section{A MORE DISCERNING APPROACH TO STUDYING CHANGE IN ORGANIC FARMING}

The review of the debate surrounding the conventionalisation hypothesis has shown that there are changes within organic farming. These transition dynamics are sometimes - if implicitly - seen as problematic in and of themselves. In this view, the pioneers are understood as the original, truest proponents of organic farming. The goal of organic farming is thus to replicate their practices, now and in the future. The original practices should not be changed or modified as it would undermine the nature of organic farming. This view presents conventionalisation as problematic, primarily because it implies a departure from the practices of the pioneers. This justification for opposing conventionalisation is questionable, if there is a lack of awareness that the converse is not necessarily the case. Indeed, although conventionalisation is a departure from the practices of the pioneers, not every departure from the practices of the pioneers is an indication of conventionalisation. We thus should no longer focus on whether organic farming is changing or not: there is ample evidence that it is. It would be more fruitful to focus on how organic farming is changing, taking care to capture the whole range of changes. 


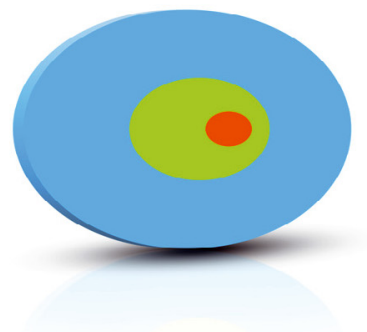

Bio-dynamic farming:

Principles and values based on anthroposophy, limited role of natural sciences, economics play a subordinate role.

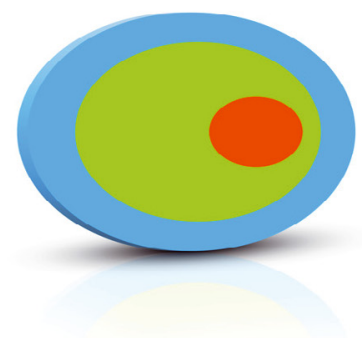

\section{Bio-organic farming:}

Values based on Christian ethics, principles built on closed cycles, emphasis on a rationalscientific approach to agro-ecology (farmer-led experiments), economics play an auxiliary role.

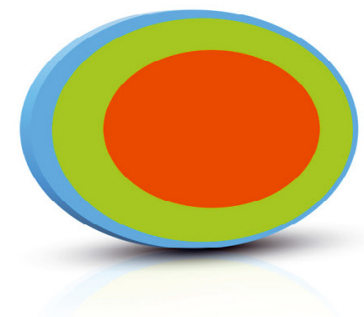

\section{Conventionalised} organic farming:

Principles and values are marginalised, narrow understanding of agroecology (reliance on scientific results), economics play a central role in on-farm decisions.

Figure 2. Schematic representation of changes in the relative importance of values, natural sciences and economics for production decisions on organic farms.

Indeed, organic farming is not a Luddite movement that seeks to turn back the clock. Organic farming should not be limited to the practices and methods of the pioneers. Not least because some of their practices, especially regarding animal welfare, were questionable (Sundrum, 2005). Rather, organic farming needs to be understood as dynamic, i.e. a system that responds to internal and external demands and conditions (IFOAM, 2005). Organic farming is thus involved in an on-going process of reviewing existing methods, assessing new technological developments, e.g. plant breeding, soil management and tillage, mechanical weed management, and implementing relevant insights from agro-ecological research (Niggli, 2007). Looking at the 1940s, it is clear that the pioneers also understood organic farming as dynamic and did not have qualms adjusting those aspects that they found unsuitable. For example, the bio-organic farming as developed by Müller and Rush is no longer based on anthroposophy, as was (and still is) the case of bio-dynamic farming (Aeberhard and Rist, 2009). Instead of using antrophosophy as their guideline, Müller and Rush have given agro-ecology and scientific thinking a much larger role (Fig. 2).

Changes are thus not problematic in and of themselves and organic farming has benefited from them in the past. Moreover, change is necessary for the survival of organic farming. Indeed, farmers now face an environment that is very different from the one faced by the pioneers: they have more regulatory constraints, but access to better developed markets; they face higher competition, but have more scientific and practical advice available to them; they face rapid changes, but have better communication possibilities. Both the constraints and the opportunities open to organic farmers are different, and as the farmers tackle these demands, it is bound to reflect on their on-farm practices.

What needs more attention is the diversity and type of changes taking place. Darnhofer (2006) has proposed to distinguish between first-order changes, i.e. changes that do not undermine the principles of organic farming (what may be termed 'professionalisation') and second-order changes. Second-order changes entail a discontinuity, they involve a shift in the rules that govern on-farm decisions. Conventionalisation can be termed as a second-order change, as the organic principles are sidelined in favour of economic profitability. Although organic farmers have always had to ensure that their farm is economically sustainable, within conventionalisation, economic considerations tend to marginalise both the principles and agro-ecology (Fig. 2).

Moving towards a more discerning analysis of the changes taking place on certified organic farms, we propose to define 'conventionalisation' as the introduction of farming practices that undermine the principles of organic farming, i.e. a second-order change. The assessment of a move towards conventionalisation should thus be based on criteria and indicators showing that the principles of organic farming are being undermined, not on structural changes (that may or may not indicate an undermining of principles). This approach implies moving away from focusing on the two extremes of 'true organic' vs. 'conventionalised'. Instead of focusing on the extremes, it might be more fruitful for research to focus on the field in-between, on the range of possibilities within organic farming. The goal is to leave organic farming room to change while providing farmers with guidance on the development paths that are in line with the principles of organic farming. 
This seems more constructive than debating whether organic farming is being conventionalised or not.

\section{TOWARDS PRINCIPLE-BASED INDICATORS OF CONVENTIONALISATION}

In this section we present a potential approach towards a principle-based indicator that would allow one to distinguish between changes that follow the principles of organic farming and those that do not. We present an outline that will require substantial further development to be applicable empirically. Our goal is not to present a polished toolbox, but to indicate a way to overcome the weaknesses of previous approaches to assessing change in organic farming. These have proven too rough and thus could not capture the developments within organic farming with the required discernment.

\subsection{Organic farming as value-based agriculture}

Organic farming has set out to be an alternative to conventional agriculture and food chains. It is based on principles and values (Luttikholt, 2007; Besson, 2008). The International Federation of Organic Agriculture Movement (IFOAM), after a concerted and participatory process, has formulated four principles to inspire action (IFOAM, 2005):

- the principle of health: "Organic agriculture should sustain and enhance the health of soil, plant, animal and human as one and indivisible";

- the principle of ecology: "Organic agriculture should be based on living ecological systems and cycles, work with them, emulate them and help sustain them";

- the principle of fairness: "Organic agriculture should build on relationships that ensure fairness with regard to the common environment and life opportunities"; and

- the principle of care: "Organic agriculture should be managed in a precautionary and responsible manner to protect the health and well-being of current and future generations and the environment".

These principles have a strong ethical component and display a much wider view of agriculture compared with the Good Agricultural Practice which may serve as a guide to conventional farming (e.g. DARD, 2008). However, these values are only partially codified in rules and regulations, thereby allowing the compromising of a more holistic vision of organic farming (Milestad et al., 2008). Indeed, the organic standards tend to focus on values and practices that are easy to codify and audit through the inspection and certification process, such as what inputs are permitted or excluded (Lockie et al., 2006; Padel, 2007). It has been argued that the dominant regulatory focus on inputs is much more likely to encourage entrants who can substitute allowed materials for disallowed materials (Rosset and Altieri, 1997; Guthman, 1998; Michelsen, 2001). Thus, the necessity of transparency in the interest of trade has made possible a rationalisation and simplification of organic meanings (Tovey, 1997; Allen and Kovach, 2000). The new European Regulation for organic production (EC, 2007) does include principles for organic production. However, not all are translated into production rules that can be part of inspection and certification (Padel et al., 2007). This mostly affects agro-ecological system values such as bio-diversity and nutrient recycling, as well as the lack of social considerations (Padel, 2007; Lockie et al., 2006). However, as Padel (2007) points out, the fact that some core values are not part of the standards does not mean that they are less important to organic stakeholders.

The organic farming associations may thus be called upon to ensure that their members do not focus exclusively on implementing the minimum requirements necessary for certification. They may also need to counter the attractiveness of exploiting legal loopholes. The goal would be for the associations to uphold the impetus to keep developing onfarm practices that implement the principles in ever more comprehensive ways. To achieve this, an assessment framework whose indicators are based on the principles of organic farming would seem a useful tool. Although developing this framework in detail is beyond the scope of this paper, we would like to propose some preliminary concepts to concretise our proposal.

\subsection{Exploring options for building an assessment framework}

The goal of developing an assessment framework is for it to serve as a tool to assess and guide future developments of organic farming methods and practices. We are aware of the practical and conceptual challenges involved in developing such an indicator set. Various authors have discussed the issues related to the necessity to cope with different units of measurement, the trade-offs between complex index measurements and simplified approaches that can be understood by practitioners who do not have a background in statistics (e.g., Andreoli and Tellarini, 2000; Malkina-Pykh and Pykh, 2008; Meul et al., 2008). Despite these hurdles, a number of models for constructing an indicator-based framework to assess sustainability of farms have already been built (e.g., van Cauwenberg et al., 2007; Knickel, 2008).

As the goal is to derive indicators from the principles, we would suggest a hierarchical framework (see van Cauwenberg et al., 2007). Figure 3 presents a concept of such a framework linking principles, criteria, indicators and reference values which are measured on different spatial scales (plot, farm, landscape). The first level of the hierarchy is made of the principles of organic farming, i.e., the general objectives to be achieved, which clearly go beyond the organic standards.

The second hierarchical level is the criterion, i.e. the resulting state or aspect of the farming system when its related principle is respected. Criteria are thus specific objectives or desirable trends. Criteria would need to encompass the environmental, economic and social functions of an organic farm. Criteria challenging the positivistic view of traditional science, such as subjective experiences, may also be considered (Lund and Röcklingsberg, 2001; Meul et al., 2008). 


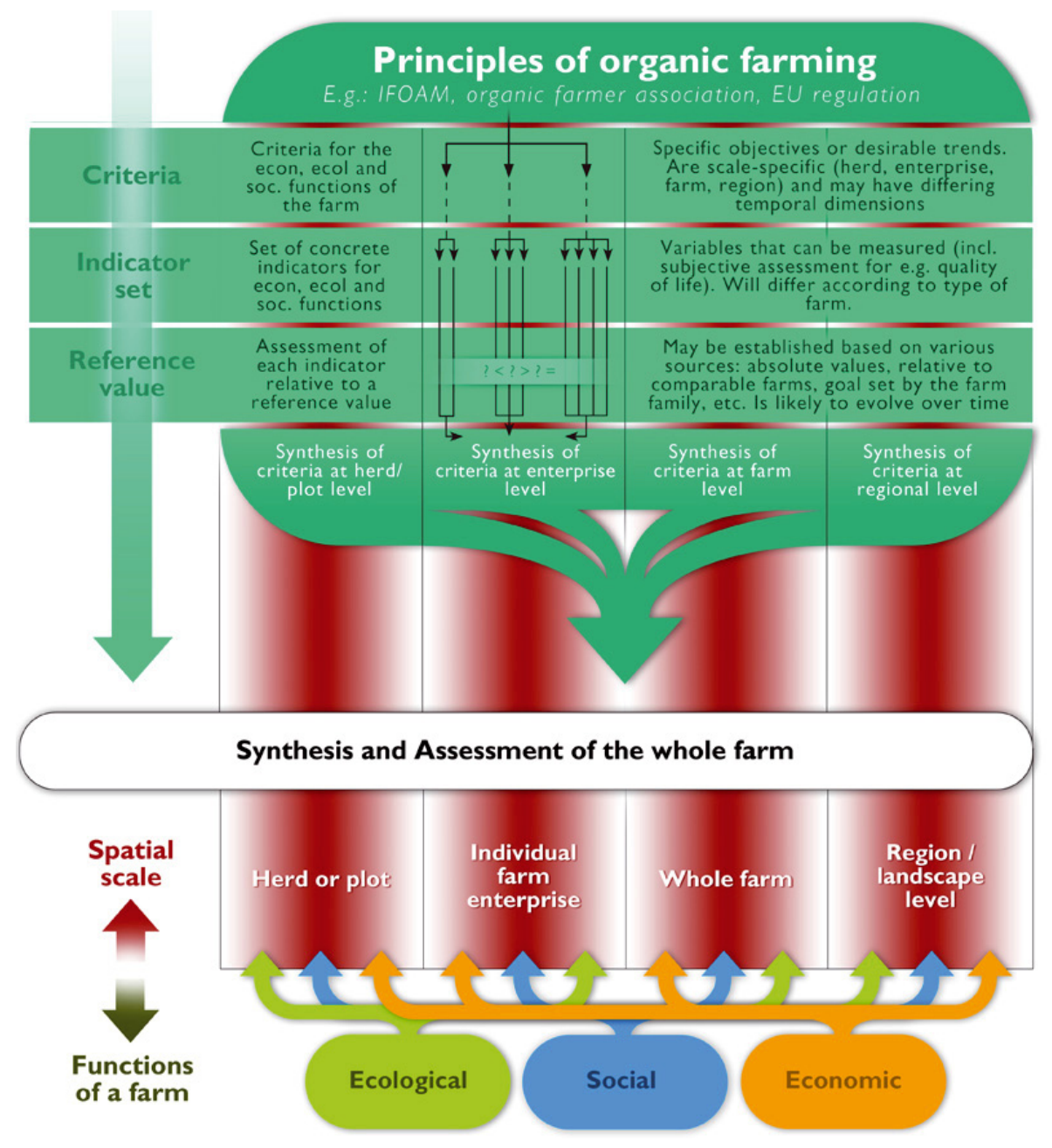

Figure 3. Schematic structure of a tool to assess the extent to which an organic farm complies with the principles of organic farming.

The third hierarchical level is the indicator. Indicators are variables of any type that are used to measure compliance with a criterion. A set of indicator values should provide a representative picture of the implementation level of the organic farming principles on a farm. The goal would thus be to ensure the selection of a core, coherent and consistent list of indicators. A number of the indicators should be site- and scale-specific as some criteria and indicators may not be relevant for all regions or all farm types. Some indicators could also be based on existing measurements, e.g. the animal needs index; the indexes used for selecting breeding animals for a number of different traits at the same time (Hazel, 1943); or indicators developed to assess the environmental performance at the farm level (Braband et al., 2003; Meul et al., 2008; Niemeijer and de Groot, 2008).

The fourth and lowest level of the framework is made up of the reference values which describe the desired level for each indicator. The reference values can be either an absolute value or a comparative value, e.g. based on similar organic farms in the same agro-ecological region. The absolute reference values might be either target values, i.e. desirable conditions, or they could be threshold values in the form of minimum or maximum levels, or a range of acceptable values.

We are aware of the contested and negotiated nature of indicators and reference values. It will be a challenge to legitimise indicators when faced with divergent claims made by different groups (Slee, 2007). The selection of the indicators and the reference values should thus be part of a participative process which includes a wide range of stakeholders (Knickel, 2008; van Ittersum et al., 2008). The discussions could be used as a tool to make the range of positions and reasoning transparent.

Such a principle-based assessment framework needs to ensure a holistic approach to organic farming, by at least being based on a whole-farm assessment. The framework needs to be based on an understanding of the farm as a complex organism, rather than the sum of more or less independent activities. The latter is a reductionistic approach that does not do justice to the systemic underpinning of organic farming. The goal would be to show the extent to which a farm implements the integrity approach, rather than the no-chemicals or the agro-ecology approach (Verhoog et al., 2003; Baars and Baars, 2007). 
The framework itself would be expected to change over time, as the principles of organic farming are refined (Luttikholt, 2007), scientific knowledge increases or societal values and concerns evolve. The goal would be to ensure a coevolutionary process, between organic farming principles, practices of organic farmers, and technical and economic feasibility as well as societal expectations.

As the assessment is based at the field, at the farm and at the landscape level, it allows the links between management by the farmer and impacts and effects on the agro-ecosystem to be addressed explicitly. This would allow the assessments derived from the framework to be used by a variety of actors: organic farmers, organic farming associations, researchers and regional policy decisionmakers. Within the framework, farms could be compared within a regional best-practice assessment. Such a regional ranking would take into account what is feasible in the region and provide each farm with a nuanced and detailed profile of the areas in which it is performing well, and those criteria where improvements seem desirable and possible. The assessment would also be dynamic since it takes into account developments and improvements in best practices.

\subsection{Examples of potential indicators for conventionalisation}

To illustrate the types of indicators that can be considered within the assessment framework, we have compiled some indicators for crop production (see Tab. I) and animal husbandry (see Tab. II). These indicators were selected focusing on those areas where practices threaten to undermine the principles. As stated in the previous section, we want to emphasise that any individual indicator is only meaningful when seen within the total constellation of a set of indicators (Niemeijer and de Groot, 2008). Indeed, an individual indicator cannot effectively capture a causal network, i.e., the whole range of causes and effects and their inter-relation. A set of indicators, however, should be able to identify the production logic underlying farm management.

Most of the indicators in Tables I and II are linked to finding "conventional" solutions to challenges faced in production and management decisions. They are mostly linked to a production logic that seeks to maximise production, i.e. aiming for yields above the level adapted to the local agro-ecological conditions, and that lacks an understanding of the interrelationships between different farm activities; and/or to short-term thinking that might be the result of economic pressures and the (perceived) need to 'cut corners', e.g., to reduce the share of legumes in the crop rotation, as legumes tend to have a low gross margin.

Indeed, a number of the indicators are linked to economic profitability, being a dominating decision criterion in conventionalised farming (Fig. 2). However, in organic farming shortterm economic aspects need to be balanced with long-term ecological and social considerations to achieve sustainability. It reflects the approach at the core of organic farming of the ethical values of stewardship and moral care for the land and thus organic farmers "say no to using chemicals, not to (always) putting every acre under tillage, not to (always) striving for the largest yield" (Stock, 2007, p. 97).

A departure from the organic principles is also reflected in practices that do not seek systemic solutions to problems, but focus on the topical alleviation of a production problem. The farm is thus not understood as a whole where each part needs to be seen in the context of the other parts. Instead, each part of the farm is perceived as separate and problems appearing in that part are solved 'locally' (separately) without considering links to other activities on the farm.

For example, a high incidence of broad-leaved dock (Rumex obtusifolius) in permanent grassland can be an indicator of intensification. It tends to be found on farms where management is guided more by economic goals and technical objectives, sidelining ecological knowledge and locally adapted management. Problems with broad-leaved dock can be linked to the application of slurry, intensive grassland use (e.g. high frequency and poor timing of mowing), as well as poor grassland management, resulting in low plant cover and soil compaction (Dietl and Lehmann 2004; FiBL, 2006). To solve the problem, it is thus usually not sufficient to reduce the number of dock plants. The farm should be seen at the systems level. For example, it might be helpful to change animal housing on those farms using litter-minimised systems, to reduce the share of concentrate in the ration (and thus reduce the nitrogen available on-farm), seek an alternative to collecting animal manure as slurry, as well as seek a grassland management appropriate for the local ecological conditions (Dietl and Lehmann, 2004).

Another example is that nutrient cycles need to be considered when selecting the number and type of animals to be kept on a farm. A specialisation in monogastric livestock (pigs, poultry) frequently reduces the share of forage legumes in the crop rotation, because this type of livestock does not use plant material rich in fibre well. Besides other challenges, the long-term consequences of such a reduction may involve severe imbalances in the farm nutrient cycles and weed problems. Systems thinking and ensuring closed nutrient cycles is a foundation of organic farming and thus needs to be the basis of all farm decisions.

\section{CONCLUSION}

Reports both in scientific journals and in popular media show that some of the developments within organic farming can lead to conventionalisation. By undermining the principles of organic farming, practices will undermine its transformative potential and thus its contribution to sustainable agriculture. However, we have shown that a number of the methods used in the conventionalisation debate do not reliably assess conventionalisation as they tend to focus on structural characteristics.

To be able to capture the changes at the farm level and be able to assess whether or not they amount to conventionalisation, a comprehensive framework built on the principles of organic farming would be useful. Indicators will need to capture the whole range of causes and effects as well as their interrelations and will clearly go above and beyond the requirements 


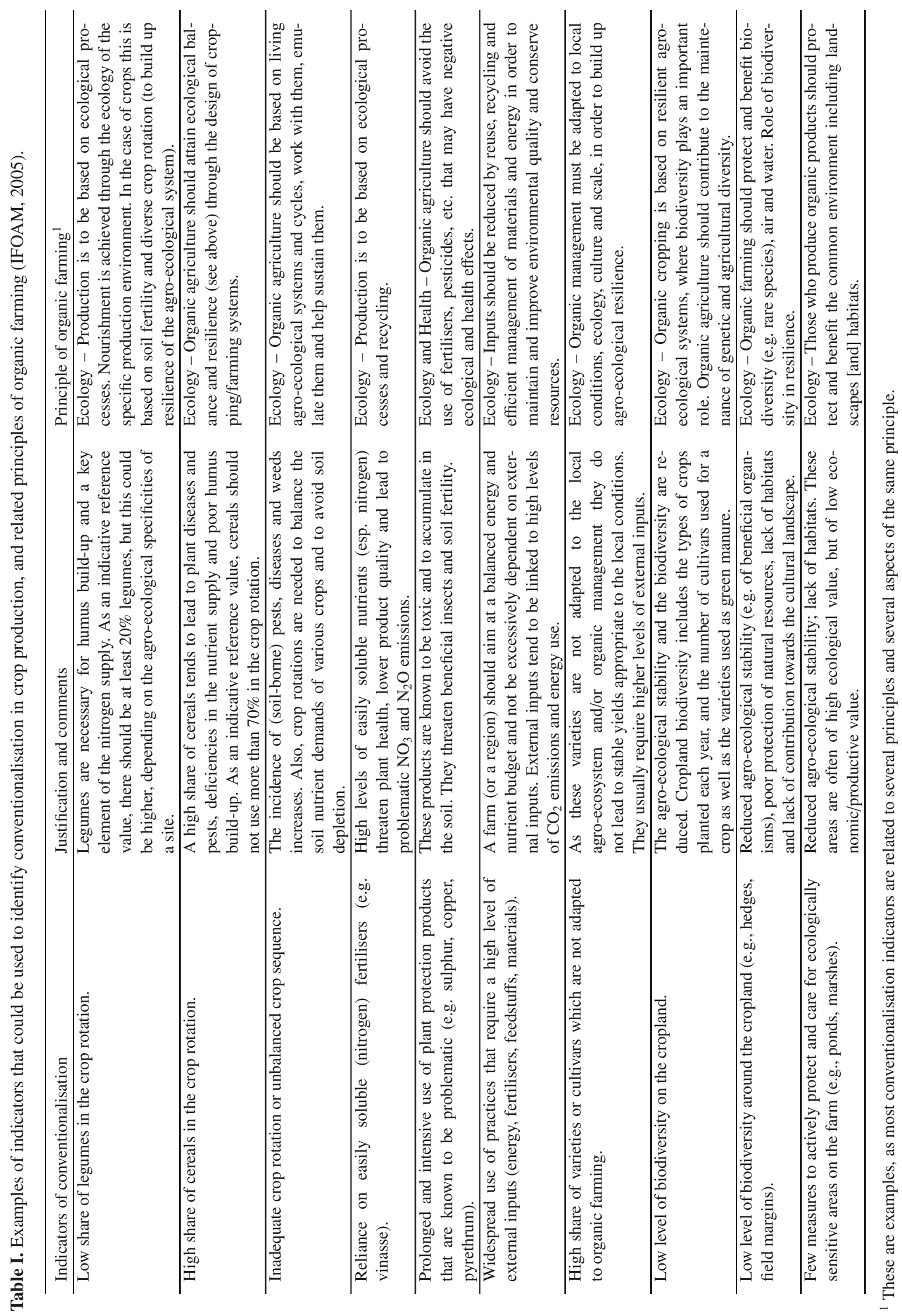




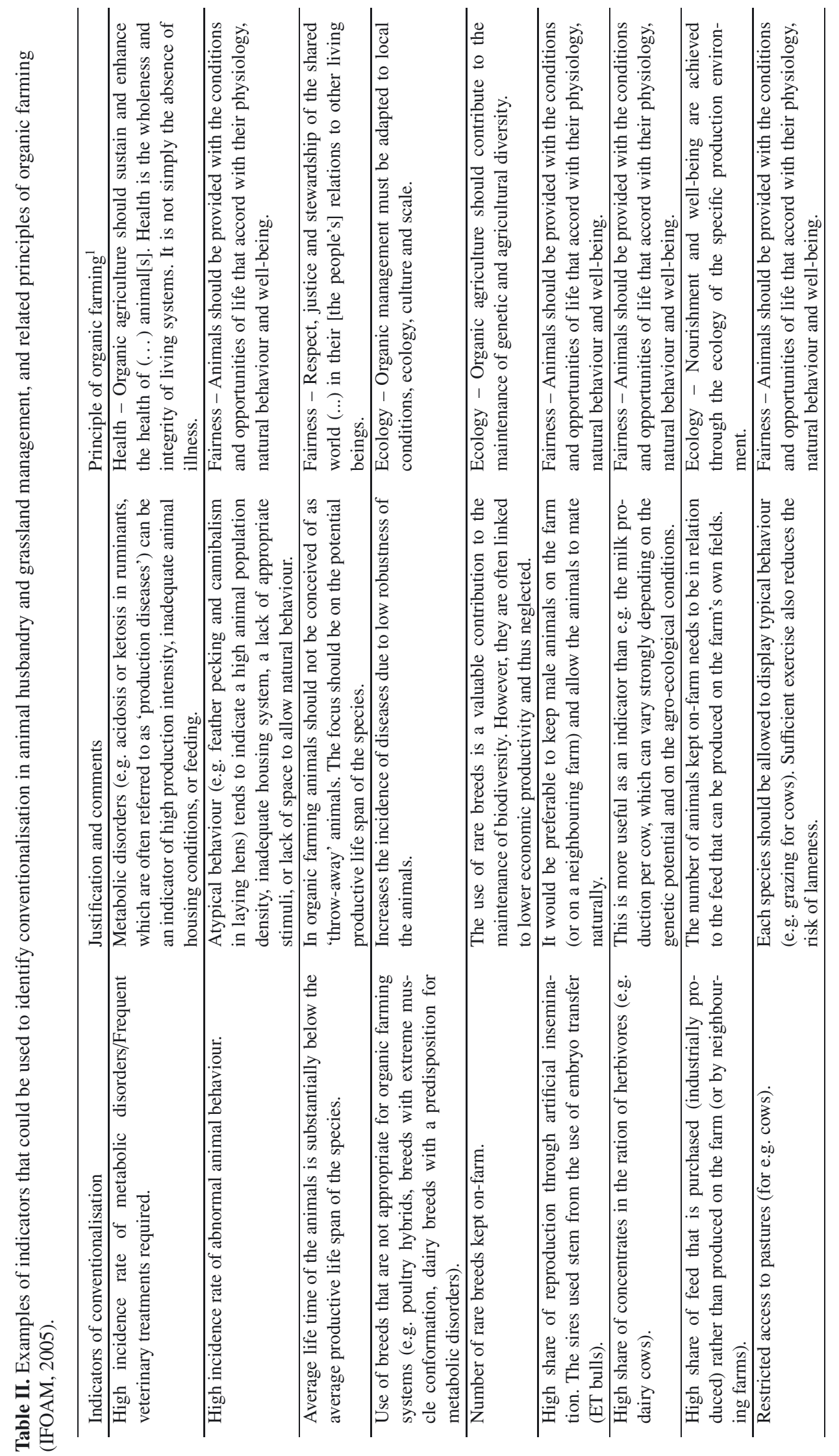




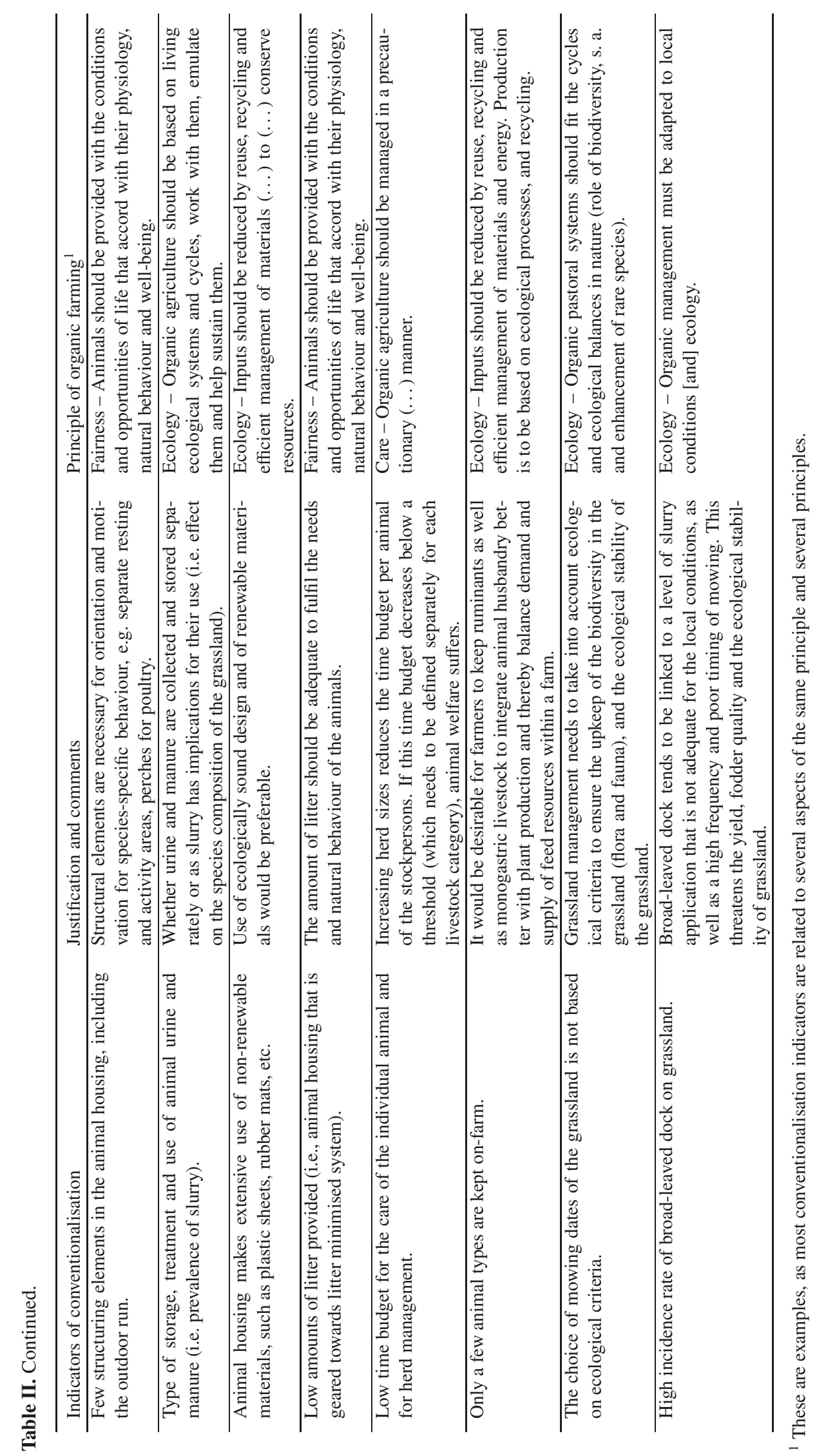


for organic certification. The indicators will need to comprehensively cover all four principles of organic farming defined by IFOAM (2005) and do justice to the systemic nature of organic farming. Defining criteria, deriving indicators and setting reference values need to be done in a participative process.

The assessment framework could be used by, e.g., organic farmer associations to provide guidance and support extension activities. Farmer associations might implement a yearly assessment to encourage farmers to implement improved practices and thus to demonstrate their commitment to the organic principles. If the assessment includes a form of certificate, the farmers can use that certificate to convey their merits to customers.

Clearly, this would not prevent some farms from opting for conventionalised practices, but it would make their (lack of) commitment to organic principles transparent. This would allow addressing the increasing heterogeneity in organic farming practices. There are farmers practising 'organic light' and those that go 'beyond organic'. If the latter are to be supported and strengthened in their resistance to conventionalisation, their contribution to agricultural sustainability must be made visible. An assessment framework explicitly based on the principles of organic farming could contribute to both the reflexivity of organic farmers and to the academic discourse regarding the changes in and further development of organic farming.

Acknowledgements: We would like to thank all those who participated in the conventionalisation workshop in May 2007 in Vienna for their open and constructive contribution and for their assessment of the changes in organic farming in Austria. We would like to thank AERU at Lincoln University for providing the supportive environment that made this paper possible. We are grateful to the anonymous reviewers and to the editor for their constructive and helpful suggestions on an earlier version of this paper. Of course, the authors alone are responsible for the content of the paper.

\section{REFERENCES}

Aeberhard A., Rist S. (2009) Transdisciplinary co-production of knowledge in the development of organic agriculture in Switzerland, Ecol. Econ. 68, 1171-1181.

Allen P., Kovach M. (2000) The capitalistic composition of organic: The potential of markets in fulfilling the promise of organic agriculture, Agr. Hum. Values 17, 221-232.

Alrøe H., Noe E. (2008) What makes organic agriculture move: protest, meaning or market? A polyocular approach to the dynamics and governance of organic agriculture, Int. J. Agr. Resour., Gov. Ecol. $7,5-22$.

Andreoli M., Tellarini V. (2000) Farm sustainability evaluation: Methodology and practice, Agr. Ecosyst. Environ. 77, 43-52.

Bähr M., Botschen M., Laberenz H., Naspetti S., Thelen E., Zanoli R. (2004) The European Consumer and Organic Food. Organic Marketing Initiatives and Rural Development, Vol. 4, University of Wales, Aberystwyth

Baars E., Baars T. (2007) Towards a philosophical underpinning of the holistic concept of integrity of organisms, NJAS-Wageningen J. Life Sci. 54, 463-477.

Besson Y. (2008) Une histoire d'exigences : philosophie et agrobiologie. Paper presented at the conference "Développement et innovation en agriculture biologique" (DinABio) held 19-20 May 2008 in Montpellier, France.
Best H. (2008) Organic agriculture and the conventionalization hypothesis: A case study from West Germany, Agr. Human Values 25, 95-106.

BMLFUW (2007) Grüner Bericht. Bericht über die Lage der österreichischen Landwirtschaft 2007 [Report on the status of agriculture in Austria in 2007], BMLFUW (Federal Ministry of Agriculture, Forestry, Environment and Water Management), Vienna.

Bowler I. (1992) The industrialisation of agriculture, in: Bowler I. (Ed.), The geography of agriculture in developed market economies, Longman, Harlow, pp. 7-31.

Braband D., Geier U., Köpke U. (2003) Bio-resource evaluation within agri-environmental assessment tools in different European countries, Agr. Ecosyst. Environ. 98, 423-434.

Brand K.W. (Ed.) (2006) Von der Agrarwende zur Konsumwende? Die Kettenperspektive [From the agricultural-turn to the consumption turn? The chain perspective]. Ergebnisband 2. Ergebnisse SozialÖkologischer Forschung Band 5. Oekom Verlag.

Buck D., Getz C., Guthman J. (1997) From farm to table: The organic vegetable commodity chain of northern California, Sociol. Rural. $37,3-20$.

Burch D., Lawrence G. (2005) Supermarket own brands, supply chains and the transformation of the agri-food system, Int. J. Sociol. Agr. Food 13, 1-18.

CEC (2004) European action plan for organic food and farming, Communication from the Commission to the Council and the European Parliament, COM(2004)415 final, Commission of the European Communities, Brussels, 7 p.

Coombes B., Campbell H. (1998) Dependent reproduction of alternative modes of agriculture: Organic farming in New Zealand, Sociol. Rural. 38, 127-145.

DARD (2008) The code of good agricultural practice for the prevention of pollution of water, air and soil (COGAP), UK Department of Agriculture and Rural Development. Available on-line at: http:// www.ruralni.gov.uk.

Darnhofer I. (2005) Organic farming and rural development: Some evidence from Austria, Sociol. Rural. 45, 308-323.

Darnhofer I. (2006) Organic farming between professionalisation and conventionalisation - The need for a more discerning view of farmer practices. Paper presented at Joint Organic Congress, Odense, Denmark, May 30-31, 2006. Available on-line at: http://orgprints. org/7390/.

De Wit J., Verhoog H. (2007) Organic values and the conventionalization of organic agriculture, NJAS-Wageningen J. Life Sci. 54, 449-462.

DeLind L.B. (2000) Transforming organic agriculture into industrial organic products: Reconsidering national organic standards, Hum. Organ. 59, 198-208.

Degré A., Debouche C., Verhève D. (2007) Conventional versus alternative pig production assessed by multicriteria decision analysis, Agron Sustain. Dev. 27, 185-195.

Dietl W., Lehmann J. (2004) Ökologischer Wiesenbau - Nachhaltige Bewirtschaftung von Wiesen und Weiden [Ecological grassland management - Sustainable management of meadows and pastures], Österreichischer Agrarverlag, Leopoldsdorf.

DuPuis E.M., Gillon S. (2009) Alternative modes of governance: organic as civic engagement, Agr. Hum. Values 26, 43-56.

EC (2004) European Action Plan for Organic Food and Farming. Commission Staff Working Document SEC(2004)739. Annex to the Communication from the Commission COM(2004)415final, 33 p. Available on-line at: http://ec.europa.eu/agriculture/organic/.

EC (2007) Council Regulation (EC) No. 834/2007 of 28 June 2007 on organic production and labelling of organic products and repealing Regulation (EEC) No. 2092/91. Published in the Official Journal of the European Union L 189, on 20.7.2007. 
EEC (2001) Council Regulation (EEC) No. 2092/91 of 24 June 1991 on organic production of agricultural products and indications referring thereto on agricultural products and foodstuffs. Published in the Official Journal L 198, on 22.7.1991.

Eurostat (2001) Organic farming. Statistics in Focus, Environment and Energy, Theme 8 - 5/2001, EuroStat, Luxembourg.

Eurostat (2007) Different organic farming patterns within EU-25. An overview of the current situation. Statistics in Focus, Agriculture and Fisheries, 69/2007, EuroStat, Luxembourg.

Fairweather J. (1999) Understanding how farmers choose between organic and conventional production: Results from New Zealand and policy implications, Agr. Hum. Values 16, 51-63.

FiBL (2006) Ampferregulierung. Vorbeugende Möglichkeiten ausschöpfen [Dock regulation - Using preventive methods]. Merkblatt von Bioland, KÖN, Bio Austria und FiBL, 16 p. Available at http:// www.fibl.org.

Flaten, O., Lien G., Ebbesvik M., Koesling M., Valle P.S. (2006) Do the new organic producers differ from the 'old guard'? Empirical results from Norwegian dairy farming, Renew. Agr. Food Syst. 21, 174-182.

Follett J. (2009) Choosing a food future: Differentiating among alternative food options, J. Agr. Environ. Ethics 22, 31-51.

Frederiksen P., Langer V. (2008) Patterns of resource use on Danish organic farms: Aspects of farmbased rural development, Int. J. Agr. Resour., Gov. Ecol. 7, 96-109.

Goodman D. (1999) Agro-food studies in the 'age of ecology': Nature, corporeality, bio-politics, Sociol. Rural. 39, 17-38.

Green K., Foster C. (2005) Give peas a chance: Transformations in food consumption and production systems, Technol. Forecasting Social Change 72, 663-679.

Guthman J. (1998) Regulating meaning, appropriating nature: The codification of California organic agriculture, Antipode 30, 135-154.

Guthman J. (2000) Raising organic: An agro-ecological assessment of grower practices in California, Agr. Hum. Values 17, 257-260.

Guthman J. (2004a) Agrarian dreams. The paradox of organic farming in California, University of California Press, Berkeley.

Guthman J. (2004b) The trouble with 'organic lite' in California: A rejoinder to the 'conventionalisation' debate, Sociol. Rural. 44, 301-316.

Guptill A. (2009) Exploring the conventionalization of organic dairy: Trends and counter-trends in upstate New York, Agr. Hum. Values 26, 29-42.

Hall A., Mogyorody V. (2001) Organic farmers in Ontario: An examination of the conventionalization argument, Sociol. Rural. 41, 399422.

Häring A.M., Dabbert S., Aurbacher J., Bichler B., Eichert C., Gambelli D., Lampkin N., Offermann F., Olmos S., Tuson J., Zanoli R. (2004) Organic farming and measures of European agricultural policy. Organic Farming in Europe: Economics and Policy, Vol. 11, University of Hohenheim, Department of Farm Economics, Hohenheim.

Hazel L.N. (1943) The genetic basis of constructing selection indexes, Genetics 28, 476-490.

Hendrickson M., James H. (2005) The ethics of constrained choice: How the industrialization of agriculture impacts farming and farmer behavior, J. Agr. Environ. Ethics 18, 269-291.

Holt G. (2006) A conceptual model of willingness to pay for organic food in the UK, in: Holt G., Reed M. (Eds.), Sociological perspectives of organic agriculture: From pioneer to policy, CABI, Wallingford, pp. 88-106.
IFOAM (2005) Principles of organic agriculture, 4 p., IFOAM International Federation of Organic Agriculture Movements, Bonn, available on-line at: http://www.ifoam.org/.

Jordan S., Shuji H., Izawa R. (2006) Conventionalization in the Australian organic industry: A case study of the Darling Downs region. In Sociological perspectives of organic agriculture: From pioneer to policy, CABI, Wallingford, pp. 142-156.

Kaut A., Mason H., Navabi A., O’Donovan J., Spaner D. (2008) Organic and conventional management of mixtures of wheat and spring cereals, Agron. Sustain. Dev. 28, 363-371.

Knickel K. (2008) Evaluating the environmental performance of farms in regionally adaptive and participatory ways, Paper presented at the conference on "Using evaluation to enhance the rural development value of agri-environmental measures" held 17-19 June 2008 in Pärnu, Estonia.

Konefal J., Mascarenhas M., Hatanaka M. (2005) Governance in the global agro-food system: Backlighting the role of transnational supermarket chains, Agr. Hum. Values 22, 291-302.

Lamine C., Bellon S. (2009) Conversion to organic farming: A multidimensional research object at the crossroads of agricultural and social sciences. A review, Agron. Sustain. Dev. 29, 97-112.

Langer V. (2002) Changes in farm level structure following conversion to organic farming in Denmark, Ame. J. Alternat. Agr. 17, 75-82.

Langer V., Frederiksen P. (2005) The development of farm size on Danish organic farms - A comment to the the conventionalisation debate. Presented at the ISOFAR, 21-23 September 2005 in Adelaide, available on-line at: http://orgprints.org/4406/.

Langmeier M., Frossard E., Kreuzer M., Mäder P., Dubois D., Oberson A. (2002) Nitrogen fertilizer value of cattle manure applied on soils originating from organic and conventional farming systems, Agronomie 22, 789-800.

Letourneau D., Bothwell S. (2008) Comparison of organic and conventional farms: challenging ecologists to make biodiversity functional, Front. Ecol. Environ. 6, 430-438.

Lobley M., Butler A., Reed M. (2009) The contribution of organic farming to rural development: An exploration of the socio-economic linkages of organic and non-organic farms in England, Land Use Pol. 26, 723-735.

Lockie S., Lyons K., Lawrence G., Mummery K. (2002) Eating "green": Motivations behind organic food consumption in Australia, Sociol. Rural. 42, 23-40.

Lockie S., Halpin D. (2005) The 'conventionalisation' thesis reconsidered: Structural and ideological transformation of Australian organic agriculture, Sociol. Rural. 45, 284-307.

Lockie S., Lyons K., Lawrence G., Halpin D. (2006) Going organic: mobilizing networks for environmentally responsible food production, CABI, Wallingford.

Lotter D.W. (2003) Organic agriculture, J. Sustain. Agr. 21, 59-128.

Lund V., Röcklingsberg H. (2001) Outlining a concept of animal welfare for organic farming systems, J. Agr. Environ. Ethics 14, 391-424.

Luttikholt L.W. (2007) Principles of organic agriculture as formulated by the International Federation of Organic Agriculture Movements, NJAS-Wageningen J. Life Sci. 54, 347-360.

Mäder P., Fließbach A., Dubois D., Gunst L., Fried P., Niggli U. (2002) Soil fertility and biodiversity in organic farming. Science 296 , pp. 1694-1697.

Malkina-Pykh I., Pykh Y. (2008) Quality-of-life indicators at different scales: Theoretical background, Ecol. Ind. 8, 854-862.

Meul M., van Passel S., Nevens F., Dessein J., Rogge E., Mulier A., van Hauwermeiren A. (2008) MOTIFS: A monitoring tool for integrated farm sustainability, Agron. Sustain. Dev. 28, 321-332. 
Michelsen J., Hamm U., Wynen E., Roth E. (1999) The European market for organic products: Growth and development. Organic Farming in Europe: Economics and Policy, Vol. 7., University of Hohenheim, Department of Farm Economics, Hohenheim.

Michelsen J. (2001) Recent development and political acceptance of organic farming in Europe, Sociol. Rural. 41, 3-20.

Milestad R., Wivstad M., Lund V., Geber U. (2008) Goals and standards in Swedish organic farming: trading off between desirables, Int. J. Agr. Resour., Gov. Ecol. 7, 23-39.

Moore O. (2008) How embedded are organic fresh fruit and vegetables at Irish farmers' markets and what does the answer say about the organic movement? An exploration using three models, Int. J. Agr. Resour., Gov. Ecol. 7, 144-157.

Nieberg H., Offermann F., Zander K. (2007) Organic farms in a changing policy environment: Impacts of support payments, EU-enlargement and Luxembourg reforms. Organic Farming in Europe: Economics and Policy, Vol. 13, University of Hohenheim, Department of Farm Economics, Hohenheim.

Niemeijer D., de Groot R.S. (2008) A conceptual framework for selecting environmental indicator sets, Ecol. Indicators 8, 14-25.

Niggli U. (2007) Mythos „Bio”. Kommentare zum gleichnamigen Artikel von Michael Miersch in der Wochenzeitung „Die Weltwoche“ vom 20. September 2007. Commentary, FiBL, Frick, available on-line at: http://orgprints.org/11368/.

Norton L., Johnson P., Joys A., Stuart R., Chamberlain D., Feber R., Firbank L., Manley W., Wolfe M., Hart B., Mathews F., Macdonald D., Fuller R. (2009) Consequences of organic and non-organic farming practices for field, farm and landscape complexity, Agr. Ecosyst. Environ. 129, 221-227.

Obach B. (2007) Theoretical interpretation of the growth in organic agriculture: Agricultural modernization or an organic treadmill? Soc. Nat. Res. 20, 229-244.

Padel S. (2007) How do ethical values of organic agriculture relate to standards and to current practice? in: Zollitsch W., Winckler C., Waiblinger S., Haslberger A. (Eds.), Sustainable food production and ethics, Wageningen University Press, Vienna, pp. 26-30.

Padel S. (2008) Values of organic producers converting at different times: Results of a focus group study in five European countries, Int. J. Agr. Resour., Gov. Ecol. 7, 63-77.

Padel S., Foster C. (2005) Exploring the gap between attitudes and behaviour - Understanding why consumers buy or do not buy organic food, Br. Food J. 107, 606-625.

Padel S., Roecklingsberg H., Verhoog H., Alroe H., De Wit J., Kjeldsen C., Schmid O. (2007) Balancing and integrating basic values in the development of organic regulations and standards: Proposal for a procedure using case studies of conflicting areas, University of Wales, Aberystwyth, available on-line at: http://orgprints.org/ 10940/.

Renting H., Oostindie H., Laurent C., Brunori G., Barjolle D., Moxnes Jervell A., Granberg L., Heinonen M. (2008) Multifunctionality of agricultural activities, changing rural identities and new institutional arrangements, Int. J. Agr. Resour., Gov. Ecol. 7, 361-385.

Rigby D., Cáceres D. (2001) Organic farming and the sustainability of agricultural systems, Agr. Syst. 68, 21-40.

Rinnofner T., Friedel J.K., de Kruijff R., Pietsch G., Freyer B. (2008) Effect of catch crop on $\mathrm{N}$ dynamics and following crops in organic farming, Agron. Sustain. Dev. 28, 551-558.

Rosin C., Campbell H. (2009) Beyond bifurcation: Examining the conventions of organic agriculture in New Zealand, J. Rural Stud. 25, 35-47.

Rosset P., Altieri M.A. (1997) Agroecology versus input substitution: a fundamental contradiction of sustainable agriculture, Soc. Nat. Resour. 10, 283-295.
Schermer M. (2006) Regional rural development: The formation of ecoregions in Austria, in: Holt G., Reed M. (Eds.), Sociological perspectives of organic agriculture, CABI, Wallingford, pp. 227-242.

Slee B. (2007) Social indicators of multifunctional rural land use: The case of forestry in the UK, Agr. Ecosyst. Environ. 120, 31-40.

Smith E., Marsden T. (2004) Exploring the 'limits to growth' in UK organics: Beyond the statistical image, J. Rural Stud. 20, 345-357.

Stock P.V. (2007) 'Good farmers' as reflexive producers: An examination of family organic farmers in the US Midwest, Sociol. Rural. 47, 83-102.

Sundrum A. (2005) Vom ökologischen Landbau zur ökologischen Landwirtschaft [From organic agriculture to organic farming], Ökologie Landbau 1/2005(133), 17-19.

Sylvander B., Bellon S., Benoit M. (2006) Facing the organic reality: The diversity of development models and their consequences on research policies, in: Organic farming and European rural development 58-59. Odense, available on-line at: http://www.orgprints.org/ $8247 /$.

Thomas F., Groß D. (2005) Von der Bewegung zur Branche. Der Ökolandbau und seine sozialen und regionalen Ziele - Eine Diskussion über Anspruch, Realität und Perspektiven [From movement to trade sector], in: AgrarBündnis (Ed.), Landwirtschaft 2005, Der kritische Agrarbericht, pp. 61-70.

Tomlinson I. (2008) Re-thinking the transformation of organics: The role of the UK government in shaping British organic food and farming, Sociol. Rural. 48, 133-151.

Tovey H. (1997) Food, environmentalism and rural sociology: On the organic farming movement in Ireland, Sociol. Rural. 37, 21-37.

Trewavas A. (2001) Urban myths of organic farming, Nature 410, 409410.

USDA (2007) Organic agriculture: US organic farm sector is diverse. Briefing Rooms, Economic Research Service, United States Department of Agriculture, on-line: http://www.ers.usda. gov/briefing/organic/Farmsector.htm.

van Cauwenbergh N., Biala K., Bielders C., Brouckaert V., Franchois L., Garcia Cidad V., Hermy M., Mathijs E., Muys B., Reijnders R., Sauvenier X., Valckx J., Vanclooser M., van der Veken B., Wauters E., Peeters A. (2007) SAFE - A hierarchical framework for assessing the sustainability of agricultural systems, Agr. Ecosyst. Environ. $120,229-242$.

van der Ploeg J.D. (1995) From structural development to structural involution: The impact of new development in Dutch agriculture, in: van der Ploeg J.D., van Dijk G. (Eds.), Beyond Modernization: The impact of endogenous rural development, van Gorcum, Assen, pp. 109-146.

van Ittersum M.K., Ewert F., Heckelei T., Wery J., Alkan Olsson J., Andersen E., Bezlepkina I., Brouwer F., Donatelli M., Flichman G., Olsson L., Rizzoli A., Van der Wal T., Wien J.E., Wolf J. (2008) Integrated assessment of agricultural systems - A component-based framework for the European Union (SEAMLESS), Agr. Syst. 96, $150-165$.

Verhoog H., Matze M., Lammerts van Bueren E., Baars T. (2003) The role of the concept of natural (naturalness) in organic farming, J. Agr. Environ. Ethics 16, 29-49.

Watson C., Walker R., Stockdale E. (2008) Research in organic production systems - past, present and future, J. Agr. Sci. 146, 1-19.

Willer H., Youssefi-Menzler M., Sorensen N. (Eds.) (2008) The world of organic agriculture. Statistics and emerging trends 2008, IFOAM and Frick: FiBL, Bonn, available at: http://www.fibl.org/. 